\title{
SOILS AND FARMING PATTERNS OF THE CENTRAL PUMICE REGION
}

\author{
R. B. Gordon
}

Farm A dvisory 0 ff icer, Taupo

\section{INTRODUCTION}

TAupo has evolved as a region of New Zealand with unique features. The volcanic ash covered some 9,000 square miles and the soils which developed, though young in geological age, were found to be highly suited to both exotic timber production and, eventually, pastoral use.

Taupo is the fount of that valuable resource - water, a vital element fully exploited by man for both electricity and trout fishing.

The town of Taupo is the focal point of the "Central Pumice Region" and is the only major centre. The region can be broadly defined as that area having the volcanic cone of Ruapehu $(9,175$ $\mathrm{ft}$ ) as the southern pillar, while in the north the Waikato River is a natural frontier from Mangakino. Both the Ikawhenua Range in the east and the Hauhungaroa in the west are natural geographic barriers. Essentially, the Taupo County lies within these natural features.

About 130 A.D. the region was covered by : series of volcanic showers known as the Taupo pumice. Successive phases blasted the region, covering it with layers of fine material (ash) and coarse pumice (lapilli) . During intervals between eruptions, geological erosion removed parts of the layers from upper slopes to lower slopes and depressions. At one stage white-hot materials were erupted and on cooling became hard and resistant to water erosion.

Size of fragment and looseness of the deposits are the main factors that are associated with soil erosion of the pumice material.

On the hills the pumice sands have developed into free-draining soils. They have been leached according to altitude and rainfall. They are naturally very low in phosphorus and the available potassium also becomes low. 
The valley floors and terraces formed of pumice sand and bouldery material are both erosion and drought prone and also weak in available nutrients.

Besides a need of phosphorus and potassium for pastures, a magnesium deficiency also develops. I n contrast with most other situations, the hills are better nutrient and moisture sustaining soils, while the valley terraces are weakest in structure, nutrients and moisture retention.

The largest infill basin is the Rangitaiki plateau at $2,500 \mathrm{ft}$ a.s.l. and consists predominantly of coarse, bouldery sands. Natural vegetation is silver tussock (Poa lcievis), monoao (Dracophyllum subulatum), various lichens and sphagnum mosses. It is windswept from the southerly quarter and is subject to severe frosts and falls of snow.

Rainfall in the Taupo region varies with altitude, ranging from 45 in. to 55 in. in the higher hill-farms, with 70 in. up on the plateau. However, annual rainfalls vary, and monthly distribution patterns change constantly. From September to April, periods with soil moisture deficiencies can be expected. Coupled with this, winds are-frequent and predominantly from a south-westerly quarter combining a desiccating and chilling effect. Frosts can occur in most months of the year and usually number 110 annually.

\section{EARLY DEVELOPMENT}

Attempts at farming were made by Butcher, Vaile and others but "bush sickness" affecting the stock was the chief retarding factor.

Early in this century large areas were devoted to the planting of exotic forests for which it proved admirably suited.

A research breakthrough proving cobalt deficiency to be the cause of "bush sickness" in the 1930s gave renewed confidence to those interested in pumiceland development. Coupled with this event was the 'important'work of Levy in selecting permanent strains of perennial ryegrass and white clover. These were later shown by Smallfield (1949) to be highly successful on the initial Ngakuru 1,100 -acre development.

After early economical difficulties the central pumice plateau boomed after World War 2 and came to the fore in pastoral farming.

The need to create farmis at an unprecedented rate to settle exiservicemen was the challenging task required of the Lands and Survey Department based at Rotorua. 
Development of unimproved land started with 1,950 acres in $1948-9$ and to date totals 416,000 acres, of which 247,200 acres have been settled. In the Taupo County itself there are still 85,500 acres farmed in 23 different blocks.

\section{SETTLEMENT}

For the central pumice region, the first to be balloted in 1950 were dairy farms on easy to broken country in the Maraetai Block at Whakamaru. In the early stages pastures grew vigorously assisted with phosphatic fertilizers. Clover abounded, particularly red clover, and this brought its problems of bloat. Units averaged 150 acres, only five paddocks, a cowshed and a part house. Initially, with 60 in-calf heifers, butterfat production was expected to be $12,000 \mathrm{lb}$ and gradually increased.

On the later developed more broken country, sheep farms were settled. Farm size was 300 to 330 acres with six watered paddocks and sometimes sheep-yards, with a woolshed to be shared by four to five farmers. Stock carried was 800 to 900 ewes, no hoggets, and 35 to 40 in-calf heifers.

In the late fifties, settlement also 'progressed in the Tirohanga and Wairakei districts.

Size of units remained small, the area depending on the contour. Ironically, the less fortunate were the smaller sized, easier contoured farms as they had a larger area of the poor fertility, coarse-textured pumice country.

With increasing economic pressures necessitating a'higher stock carrying capacity for the units to budget out satisfactorily, the size of new sheep farms has also had to be increased. In the last five years this has gone from 440 acres carrying 1,800 stock units (s.u.) to 470 acres carrying 2,300 s.u. The current ex-dairy units have been restructured into sheep farms of up to 530, acres.

More capital items are now provided, nine watered paddocks, woolshed with yards and haybarn. This, and the increased, costs of land development, has meant an increased deposit by candidates for settlement. Requiring $\$ 8,000$ five years ago, it now needs $\$ 12,250$, on a leasehold basis. Because of the financial hurdle, most units are taken up on leasehold. Total ingoing costs for land, stock and plant are now of the order of $\$ 80,000$. With the new settler's contribution of $\$ 12,000$, he has an ingoing equity of only $20 \%$.

Carrying capacity at settlement is 2,300 s.u., giving 4.8 s.u. per acre. On present knowledge and experience., the area is 
capable of improvement to $61 / 2$ s.u. per acre but only with good management.

The principal sheep farming pattern is breeding own replacements, using predominantly Romney, and fattening wether lambs.

To improve lambing percentages and ease of lambing there is a strong surge of interest in Perendales of recent years.

\section{PUMICELAND PIONEERING PROBLEMS}

Dairy farming in a sea of clover inevitably leads to nightmares of bloat. This, and. the problem of rearing young stock, limited herd improvement and increased the number of cows milked.

Ragwort (Senecio jacobaea) perpetually abounded and was a dominant factor preventiag dairy farming becoming a viable proposition in the Maraetai Block.

The continuous use of various chemicals to achieve control, combined with inadequate potassic fertilizer, inevitably led to serious clover and pasture deterioration. Coupled with successive years of frequent dry spells and an exploding grass grub prob$1 \mathrm{~cm}$. it culminated in the phasing out of some 60 dairy farms and the restructuring of these into sheep units.

The sheep farmer's share of problems was heralded with young lambs dying under movement stress, and so only 40 to $50 \%$ lambing resulted, combined with large numbers of dry ewes. Severely affected were the newly settled units around Wairakei. This was subsequently shown to be due to a selenium deficiency.

Erosion also occurred at an increasing rate, particularly on the coarse infill valleys and, to alleviate this, areas required to be fenced out and retired. The loss of valuable acres also resulted from the cvergrowth of residual pine trees and even to the encroachment of thermal activity on some units. Such factors have necessitated either resettlement. review of charges, or assistance in the purchase of more land.

Deterioration in clover vigour was another difficulty in older established areas. This has been considerably improved bv realizing the role of both sulphur and potash in plant nutrition and the necessity of proper timing of fertilizers on these readily leache d s o i $1 \mathrm{~s}$.

\section{RESEARCH}

The region has had more than its share of problems and unfortunatcly it is only in latter years that there has been a more adequate research programme. 
In 1958 the 367 acre Wairakei Soil Conservation Reserve was acquired, while in 1970 it became one of the stations under the Research Division.

Valuable investigations for the district have bzen carried ou!, not the least of which are those relating to ali facets of lucerne growing.

Extensive trial work involving animal health, soil fertility and grass grub has been carried out in the field on various farms.

\section{PASTURES: THEIR PRODUCTION AND PESTS}

Annual productions of $8,000 \mathrm{lb} \mathrm{DM} / \mathrm{ac}$ have been recorded on the hill soils. However, on the droughty flats these averags. only 5,000 lb DM/ac. The peak of pasture production normally occurs in December when both moisture and temperature synchronize

White clover nodulation, while appearing satisfactory, suffers from the fact that the degree of rhizobial activity seems to be strongly correlated with the shallow siting of nodules on clover roots. Much of the clover rooting is enmeshed in the turf mat. This layer readily succumbs to drying conditions. Hence pastures often suffer from low nitrogen status inder the frequent adverse climatic stresses. A turf mat of up to an inch thick which builds up on these pumice soils is well known.

The plateau soils of $2,000 \mathrm{ft}$ and above singularly lack clover rhizobia. Here inoculation of clover seed is a vital prerequisite along with adequate fertilizers covering a wide range of nutrient deficiencies.

Suitable earthworms are lacking and widespread introduction attempts have been made. However, the dungworm (Lumbricus rubellus) is widespread and its beneficial effects are apparent.

All soils appear to have a sharp gradient of fertility in relation to the depth of the topsoil. The major available nutrient supply appears to be in the top $1 \mathrm{in.}$ zone.

Soil $\mathrm{pH}$ is invariably around 5.6 but to date pastures have failed to respond to any degree from lime. However, where it has been shown to be lacking, molybdenum has considerably improved clovers and led to pasture regeneration.

The grass component of swards on the hill country varies considerably. There is generally a iarge amount of Yorkshire fog and some cocksfoot with native grasse's. Ryegrass is limited and low in vigour. Much of the hills requires improvement but whether this can be achieved by introducing only ryegrass is open to doubt. 
Grass grub has plagued the district since development. Initially it was controlled with powdered forms of DDT, but latterly only with limited success using pellets. Again, it is seriously destroying pastures and denuding hill faces.

The major weed problem throughout the district is nodding thistle (Carduus nutans). Recent successive dry seasons and the opening up of pastures have led to a large increase in the thistle population.

\section{LUCERNE}

Where pastures produce only 5,000 lb DM/ac/annum on the droughty flats, lucerne has yielded $12,000 \mathrm{lb} \mathrm{DM} / \mathrm{ac} / \mathrm{annum}$. Its virtue is obvious and its establishment techniques must be precise to be successful. Costs, without cultivation, are $\$ 40 / \mathrm{ac}$ and maintenance of high production requires some $\$ 20 / \mathrm{ac} / \mathrm{annum}$ for fertilizers and lime.

Recognition of the value of lucerne has been slow' and this is illustrated by the rapid increase in the area established in recent drought years.

\section{ANCILLARY AND SERVICING INDUSTRIES}

Taupo is an inland centre and the district is serviced completely by roads, the nearest rail-head being 40 miles away.

Road transport carries all stock and farm. requirements. Because of the district's central situation, stock can be sent for slaughter to freezing works in several directions.

For stock sales, major fairs are held in the district while the yards at Rotorua provide the nearest regular sale centre.

Co-operative fertilizer works at Napier and Mt Maunganui, and also a proprietary one at Morrinsville, supply the fertjlizer so essential for the district. The area is well served, by aerial and bulk fertilizer topdressing contractors. Recently two new bulk fertilizer depots have been established to provide the service necessary for the region.

\section{CONCLUSION}

Finally, to present-day farmers and, not the least, to those yet to come, let it be said that, with skill and determination and assisted by advanced technology, efficient and economical *progress in pastoral farming on the central pumicelands is possible.

\section{REFERENCE}

Smallfield, P. W., 1949: Proc. N.Z. Grassld Ass., 11: 59-67. 


\section{DISCUSSION}

To a question from Thorpe (Paeroa) on the best time for fertilizer application in the district, Gordon said that it must be before the expected growth pattern which was usually in August. This helped early spring growth considerably. It had been found that split applications gave a more beneficial effect - one in August for spring growth and the second in early December to stimulate late summer and early autumn production. Banfield (Hamilton) commented that this was a special problem in the Taunn area and would not necessarily annly in Paeroa. Schofield (Taumarunui) inquired as to whether grass grub was serious in the area and which was more important, chemical control or an increase in the use of fertilizer. Gordon replied that it was a most serious problem, particularly in the Whakamaru area, where the grub was extending on a wide front in the hill country. Here it was hard to control because of difficulty in application. Grass grub was also a serious problem in other areas. He thought it would possibly be better to divert' finance from fertilizers to control measures but realized these have technical difficulties in application and level of effectiveness. McLachlan (Taupo) asked if lucerne could be envisaged as a grazing proposition rather than for hay. Gordon stated that a great potential for grazing lucerne had been demonstrated at the Wairakei Research Station and also by some farmers. Controlled grazing gave effective utilization and lucerne persistence provided adequate fertilizer was applied. Duder suggested that an increase in $\mathrm{pH}$ down the soil profile might favour deeper rooted luceme compared with shallow rooted clovers. However, Gordon thought that the $\mathrm{pH}$ figure in the example given in the table was an exception to the rule and that not too much notice should be taken of it. Candy (Ngatea) asked what constituted controlled grazing of lucerne. Gordon defined this as using large numbers of animals to graze down rapidly within 5 or 6 days. This gave good utilization without checking regrowth of tillers. Leitch (Taupo) inquired whether the turf mat which formed in young pastures continued to build up and whether it would be affected by the relationship between liming and earthworm populations. Gordon stated that it was only in the poorer pastures, inadequately fertilized and with poorer species, that the turf mat built up significantly: In vigorous pastures the mat was thinner and did not increase. As far as earthworms and liming were concerned, it was the calcium requirement that was important, rather than the $\mathrm{pH}$ status. In spite of liming, desirable earthworm species are proving very slow to colonize. 